\title{
Utilization of agricultural waste in Pardomuan Motung Village, Ajibata Subdistrict, Toba Samosir Regency
}

\author{
Achmad Sadeli $^{1 *}$, Adil Ginting ${ }^{2}$, Lina Tarigan ${ }^{3}$ \\ ${ }^{1}$ Department of Animal Husbandry, University Sumatera Utara \\ ${ }^{2}$ Department of Chemistry, University Sumatera Utara \\ ${ }^{3}$ Department of Public Health, University Sumatera Utara \\ *Email: achmadsadeli@usu.ac.id
}

\begin{abstract}
Agriculture is the activity of utilizing biological resources carried out by humans to produce food, raw materials or energy sources, and to manage their environment. The use of biological resources included in agriculture is commonly understood by people as crop cultivation or farming (English: crop cultivation) and raising livestock (raising), even though its scope can also be in the use of microorganisms and bioenzymes in processing advanced products. Based on the analysis of the situation in Pardomuan Motung Village, the problems obtained include environmental conditions which are agricultural areas that produce a lot of waste through agricultural and livestock products caused by the lack of community knowledge about waste treatment.
\end{abstract}

Keyword: Agricultural Waste, Pardomuan Motung Village

\begin{abstract}
Abstrak
Pertanian adalah kegiatan pemanfaatan sumber daya hayati yang dilakukan manusia untuk menghasilkan bahan pangan, bahan baku atau sumber energi, serta untuk mengelola lingkungan hidupnya. Kegiatan pemanfaatan sumber daya hayati yang termasuk dalam pertanian biasa dipahami orang sebagai budidaya tanaman atau bercocok tanam (bahasa Inggris: crop cultivation) serta pembesaran hewan ternak (raising), meskipun cakupannya dapat pula berupa pemanfaatan mikroorganisme dan bioenzim dalam pengolahan produk lanjutan. Berdasarkan analisa situasi di Desa Pardomuan Motung, maka permasalahan yang didapat diantaranya adalah kondisi lingkungan yang merupakan daerah pertanian yang menghasilkan banyak limbah melalui hasil pertanian dan peternakan yang disebabkan oleh minimnya pengetahuan masyarakat tentang pengolahan limbah tersebut.
\end{abstract}

Kata Kunci: Limbah Pertanian, Desa Pardomuan Motung

\section{PENDAHULUAN}

\subsection{Latar Belakang.}

Pardomuan Motung merupakan salah satu desa di Toba Samosir yang berada di Kecamatan Ajibata. Pardomuan Motung diapit oleh beberapa desa, yaitu disebelah utara berbatasan dengan pardomuan ajibata, di sebelah selatan berbatasan dengan motung, di sebelah barat berbatasan dengan horsik, di sebelah timur berbatasan dengan pardomuan ajibata.

Pardomuan motung memiliki luas $6,0 \mathrm{~km}^{2}$ dengan jumlah penduduk sebanyak 513 Jiwa (2019), dengan Kepala keluarga 122 Jiwa dengan jumlah Laki - laki 239 Jiwa, perempuan 274 Jiwa. Berdasarkan kelompok umur, 0 - 15 tahun berjumlah 60, kelompok umur 15 - 65 tahun berjumlah 303, kelompok umur 65 ke atas berjumlah 47 Jiwa. Berdasarkan data desa pada tahun 2019 mata pencaharian masyarakat di Desa Pardomuan Motung yang tertinggi adalah petani.

Pertanian adalah kegiatan pemanfaatan sumber daya hayati yang dilakukan manusia untuk menghasilkan bahan pangan, bahan baku atau sumber energi, serta untuk mengelola lingkungan hidupnya. Kegiatan pemanfaatan sumber daya hayati yang termasuk dalam pertanian biasa dipahami orang sebagai budidaya tanaman atau bercocok tanam (bahasa Inggris: crop cultivation) 
serta pembesaran hewan ternak (raising), meskipun cakupannya dapat pula berupa pemanfaatan mikroorganisme dan bioenzim dalam pengolahan produk lanjutan.

Dikarenakan banyaknya mata pencaharian masyarakat di Desa Pardomuan Motung sebagai petani dan juga peternak, maka banyak limbah limbah pertanian seperti kulit kopi, jerami padi, limbah sayuran, jerami jagung,dan juga limbah peternakan seperti kotoran sapi, kotoran kerbau, kotoran unggas dan kotoran babi. Dimana limbah ini tidak diolah dan hanya dibiarkan saja.

Berdasarkan analisa situasi di Desa Pardomuan Motung, maka permasalahan yang didapat diantaranya adalah kondisi lingkungan yang merupakan daerah pertanian yang menghasilkan banyak limbah melalui hasil pertanian dan peternakan yang disebabkan oleh minimnya pengetahuan masyarakat tentang pengolahan limbah tersebut.

Maka dari permasalahan - permasalahan diatas diperlukan peran agent of change untuk menangani dan membantu dalam menyelesaikan masalah yang dihadapi saat ini, melalui kegiatan KKN - PPM (Kuliah Kerja Nyata - Pembelajaran Pemerdayaan Masyarakat) Desa Pardomuan Motung Kecamatan Ajibata Kabupaten Toba Samosir di harapkan dapat menanggulangi dan mengurangi permasalahan limbah pertanian dan peternakan Desa Pardomuan Motung sehingga dapat memberdayakan kearifan lokal dan potensi desa menuju masyarakat cerdas, kreatif, dan mandiri sesuai dengan tema KKN - PPM USU 2019.

\subsection{Maksud dan Tujuan}

a. Untuk menghindari pencemaran yang diakibatkan oleh limbah hasil pertanian

b. Memanfaatkan limbah pertanian untuk menghasilkan suatu produk baru yang dapat digunakan kembali untuk pertanian

c. Meningkatkan hasil pertanian melalui olahan produk baru

d. Meningkatkan kesejahteraan masyarakat melalui meningkatnya hasil pertanian

\subsection{Manfaat}

Dengan dilakukannya sosialisasi pemanfaatan limbah pertanian sebagai pupuk kompos kiranya dapat meningkatkan pengetahuan kelompok tani untuk meningkatkan hasil pertanian masyarakat Desa Pardomuan Motung.

\section{METODE PELAKSANAAN}

- Hari / Tanggal Sosialisasi : Senin, 19 Agustus 2019

- Lokasi

- Pukul

- Tujuan

- Manfaat

- Sasaran

- Metode Pelaksanaan
: Kantor Kepala Desa Pardomuan Motung

: $13.00 \mathrm{WIB}$

: Mensosialisasikan pemanfaatan limbah pertanian di Desa Pardomuan Motung

: Masyarakat semakin tahu, mau dan mampu mengolah dan memanfaatkan limbah pertanian di Desa Pardomuan Motung.

$$
\text { : Kelompok petani }
$$

Untuk mencapai tujuan kegiatan sosialisasi secara baik dan terarah diperlukan metode atau cara - cara penyuluhan pertanian yang bersifat memimbing dan mengarahkan sehingga para petani - peternak dapat "menolong dirinya sendiri", mengubah memperbaiki pola pikir, tingkat kerja dan tingkat kesejahteraan hidupnya.

Metode yang digunakan ialah metode pendekatan kelompok (Group Approach Method) yang dilakukan terhadap kelompok tani dimana para petani diajak, didampingi serta diarahkan untuk 
melaksanakan suatu kegiatan yang tentunya lebih produktif yang dilaksanakan melalui pendemonstrasian secara langsung di hadapan kelompok tani tersebut .

\section{HASIL DAN PEMBAHASAN}

Kompos merupakan salah satu pupuk organik yang digunakan pada pertanian untuk mengurangi penggunaan pupuk anorganik. Penggunaan kompos dapat memperbaiki sifat fisik tanah dan mikrobiologi tanah. Kompos memiliki kandungan unsur hara seperti nitrogen dan fosfat dalam bentuk senyawa kompleks argon, protein, dan humat yang sulit diserap tanaman. Berbagai upaya untuk meningkatkan status hara dalam kompos telah banyak dilakukan, seperti penambahan bahan alami tepung tulang, tepung darah kering, kulit batang pisang dan biofertilizer (Dasumiati, 2015)

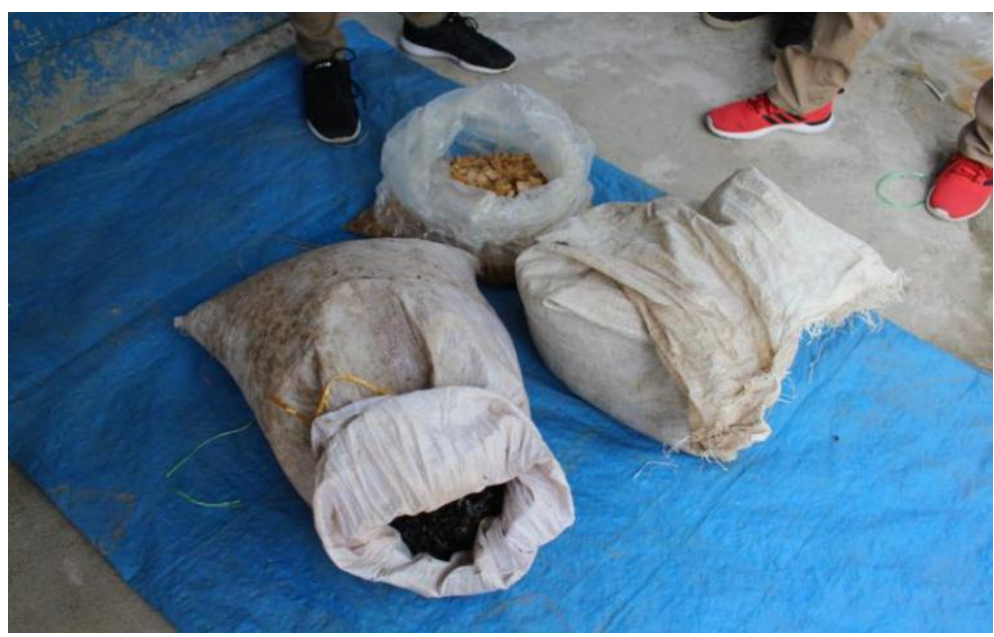

Gambar 3.1 Limbah Pertanian berupa kulit kopi

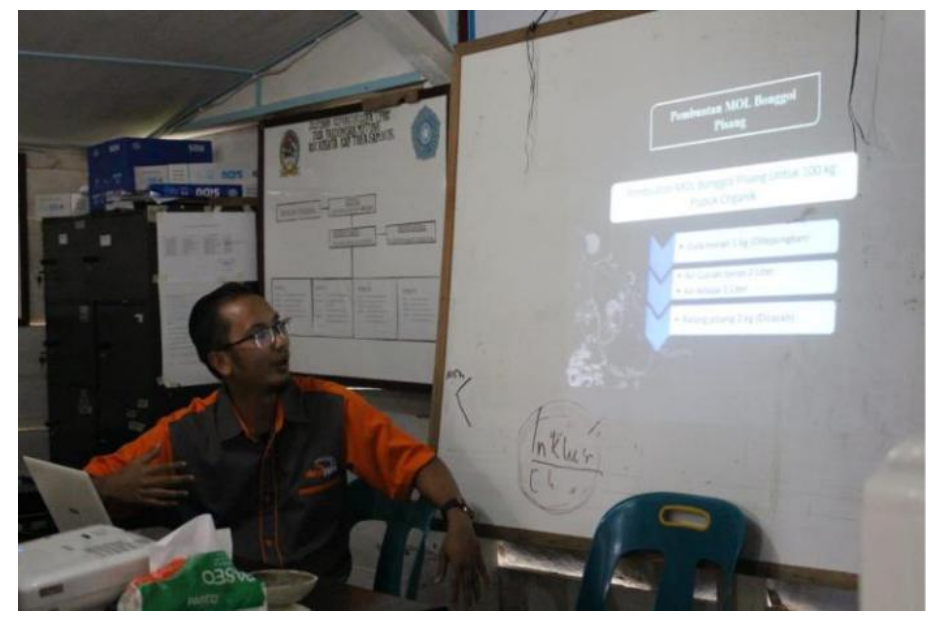

Gambar 3.2 sosialisasi pemanfaatan limbah pertanian

Sosialisasi pada hakikatnya merupakan suatu kegiatan yang bertujuan untuk menciptakan perubahan. Perubahan yang terjadi dharapkan dapat meningkatkan kesejahteraan bagi sasaran penyuluhan. Peruahan terseut meliputi perubahan pengetahuan, sikap dan tindakan. Pengetahuan dikatakan meningkat bila terjadi perubahan dari tidak tahu menjadi tahu dan yang sudah tahu menjadi lebih tahu. Sikap dikatakan meningkat, bila terjadi perubahan dari yang tidak mau menjadi mau, memanfaatkan kesempatan - kesempatan yang di ciptakan. Tindakan dikatakan meningkat bila terjadi perubahan diri yang tidak mampu menjadi mampu melakukan sesuatu yang bermanfaat dan produktif. 


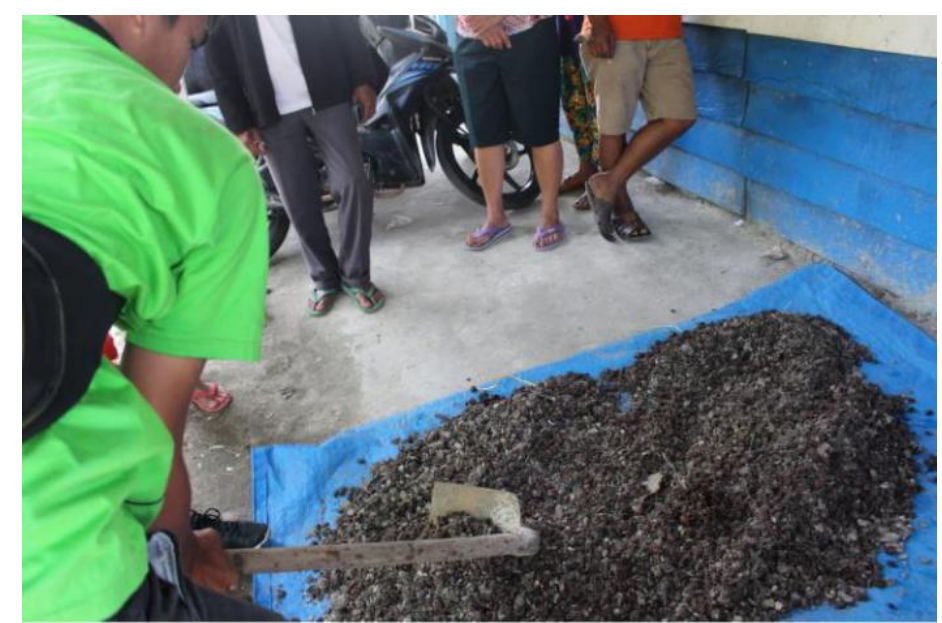

Gambar 3.3 praktik pembuatan kompos dari limbah pertanian

Berdasarkan program yang telah dilaksanakan, maka hasil yang di peroleh ialah Masyarakat menjadi tahu, mau dan mampu dalam mengolah dan memanfaatkan limbah pertanian.

\section{KESIMPULAN}

Kompos merupakan salah satu pupuk organik yang digunakan pada pertanian untuk mengurangi penggunaan pupuk anorganik. Penggunaan kompos dapat memperbaiki sifat fisik tanah dan mikrobiologi tanah. Kompos memiliki kandungan unsur hara seperti nitrogen dan fosfat dalam bentuk senyawa kompleks argon, protein, dan humat yang sulit diserap tanaman. Berdasarkan program yang telah dilaksanakan, maka hasil yang di peroleh ialah Masyarakat menjadi tahu, mau dan mampu dalam mengolah dan memanfaatkan limbah pertanian

\section{UCAPAN TERIMAKASIH}

Terimakasih kami ucapkan kepada bapak Rektor USU, Wakil Rektor III dan Ketua LPPM USU yang telah mendukung pendanaan pelaksanaan kegiatan pengabdian masyarakat ini.

\section{DAFTAR PUSTAKA}

Dasumiati.E.S. 2015. Optimalisasi Penggunaan Pupuk Kompos Dengan Penambahan Effective Microorganism 10 (Em10) Pada Produktivitas Tanaman Jagung (Zea Mays L.). Fakultas Sains Dan Teknologi Uin Syarif Hidayatullah Jakarta

Irawan. B.2014. Pengaruh Susunan Bahan Terhadap Waktu Pengomposan Sampah Pasar Pada Komposter Beraerasi. Akin St.Paulus, Semarang. 